\title{
Navigating conservation strategies: linking material research on alum-treated wood from the Oseberg collection to conservation decisions
}

\author{
Susan Braovac ${ }^{1 *}\left(\mathbb{0}\right.$, Caitlin M. A. McQueen ${ }^{1}$, Malin Sahlstedt ${ }^{1,3}$, Hartmut Kutzke ${ }^{1}$, Jeannette J. Łucejko² \\ and Torunn Klokkernes ${ }^{1}$
}

\begin{abstract}
From the mid-1800s to the late 1950s, conservation by alum salts (aluminum potassium sulfate dodecahydrate) with some variations - was a routine method for treating highly deteriorated waterlogged archaeological wood in many countries, especially in Scandinavia. It was eventually replaced by newer methods in the 1960s, such as that using polyethylene glycol. Accordingly, the signs of deterioration in such collections and the reasons behind them are not well known among current preservation specialists. The research in the Saving Oseberg project (2014-2019) has shed light on the consequences of this treatment and reasons behind the severe deterioration observed today in many objects of the Oseberg Viking Age wooden finds, which were conserved in the early 1900s. Saving Oseberg aims to provide research-based recommendations for the future preservation of the finds, and as such, a large part of the project is aimed at improving our understanding of this complex material. Here the consequences of the method are summarized, drawing on the research to date. Chemical analyses of the Oseberg wood showed its current condition to be highly degraded: little polysaccharide content is left and the lignin is significantly oxidized and extensively depolymerized. The conservation implications are also discussed.
\end{abstract}

Keywords: Oseberg find, Wood degradation, Alum-treated wood, Alum, Potassium aluminum sulfate, Ammonium aluminum sulfate, Chemical analyses, Retreatment, Saving Oseberg

\section{Introduction}

Museum collections conserved by discontinued treatments may require specialized knowledge to enable their proper care. This is especially true in cases where older conservation treatments are the cause of unacceptable damage, sometimes only revealed after a great elapse of time. At the Museum of Cultural History (KHM) it took almost 100 years for observable damage, such as new cracks, to manifest itself on a collection of archaeological wooden objects which were conserved in the early 1900 s by a once widely used method which is now

\footnotetext{
*Correspondence: susan.braovac@khm.uio.no

${ }^{1}$ Department of Collection Management, Museum of Cultural History,

University of Oslo, Postbox 6762, St. Olavs plass, 0130 Oslo, Norway

Full list of author information is available at the end of the article
}

obsolete. This method used alum salts (potassium aluminum sulfate dodecahydrate, $\left.\mathrm{KAl}\left(\mathrm{SO}_{4}\right)_{2} \cdot 12 \mathrm{H}_{2} \mathrm{O}\right)$ to preserve highly degraded archaeological waterlogged wood. It was actively in use from the mid-1800s to the 1950s, especially in Scandinavia [1-4]. Many collections may therefore have alum-treated wooden objects. However, due to the fact that this method is no longer in use and knowledge about it is limited, preservation professionals may not be aware of how to identify alum-treated wood nor understand reasons behind the observed damage.

At KHM, alum salts were used to conserve a significant portion of the wooden objects from the Oseberg mound, a Viking Age ship burial for two women constructed in 834 AD, located near Tønsberg, Norway and excavated in 1904 [5]. This collection represents one of the richest, most complete collections of Viking Age wooden 
objects in the world: alongside textiles and metal objects, lay ornately carved wooden objects such as a ceremonial wagon, three ceremonial sleds, animal head posts and hundreds of everyday artefacts [6]. The find is exhibited at the Viking Ship Museum in Oslo. ${ }^{1}$

We now know that the alum treatment has caused both chemical and mechanical degradation of the wood. To chemically and physically stabilize alum-treated objects from the Oseberg find-which present challenges in terms of variability in condition, size and in degree of restoration-a combination of preventive and invasive reconservation approaches is needed. However, successful preservation strategies can only be designed if the causes of the observed damage are understood. Few details about the alum treatment method are recorded in archival and published sources, and previous research did not investigate the material's chemical properties [4, 7]. For this reason, the Alum Research Project (20072013) and later the Saving Oseberg (SO) research project (2014-2019) were established at KHM. Initially, research was directed towards investigating chemical and physical properties of the material in order to gain a better understanding of the reasons behind the observed deterioration. Currently, we continue to investigate the chemical properties but also are investigating reconservation methods. Although much of this research has been published, the newly gained material knowledge has not yet been brought together into a broader preservation perspective. This paper summarizes what we know thus far about the material and discusses how it impacts the main preservation issues, using the Oseberg collection as a case study. The information presented here about alum-treated wood from the Oseberg finds adds to previous works $[1,4,7]$ and provides means to identify and interpret the signs of degradation in alum-treated wood in other collections.

\section{Background}

\section{Condition of the Oseberg finds upon excavation}

Approximately 5000 tons of turf and large stones sealed the burial mound. This load had caused compression of the blue clay upon which the ship rested, crushing the grave contents $[6,8]$. The large amount of organic material recovered from the Oseberg mound is attributed to relatively stable water levels released from the blue clay mass lining the base of the mound [8]. Water, together with the turf cover, created an almost anoxic state favouring the slow action of bacterial decay. The recovered waterlogged wooden objects were deteriorated to varying

1 The Viking Ship Museum is administered by the Museum of Cultural History, University of Oslo (KHM). degrees in the burial mound, roughly following wood genus.

The oak ship and objects made of oak, ash, yew and pine, were in relatively good condition and could be air dried. However, a large portion of the objects were made from various hardwoods, such as maple, alder, birch and possibly beech, and were highly deteriorated upon recovery. These woods needed to be conserved before drying. Prior to their transport to Oslo, all wooden objects, except for the ship fragments, were surface-cleaned on-site and packed in wet moss and burlap. Upon their arrival, they were placed into zinc containers filled with water, to which a small amount of the biocide sublimate (mercuric chloride, $\mathrm{HgCl}_{2}$ ) had been added [6].

\section{Finds treated with alum}

In the 1800s treatments for waterlogged archaeological wood were based on the application of coatings using various solvents, oils and waxes which did not lend support to the wood's cellular structure in severely deteriorated objects [9]. In the late 1850s, the recovery of vast amounts of highly degraded waterlogged archaeological wood from the Vimose find in Denmark stimulated research into alternative conservation treatments at the National Museum of Denmark. In 1861 Christian Frederik Herbst, archaeologist at the National Museum of Denmark published-simultaneously with C.A. Speerschneider of Glücksburg Castle, Germany-the first known accounts of treatment with alum salts, which they had developed independently $[10,11]$.

After ca. 1910, glycerol appears to have become a standard addition to the alum-treatment despite the fact that the object became extremely sensitive to ambient relative humidity due to the hygroscopic glycerol, often resulting in its complete destruction within only a few decades [1]. Glycerol was not used on the Oseberg finds, even though it was being experimented with in 1904.

Professor Gabriel Gustafson, who led the Oseberg excavations on behalf of the University Museum of Antiquities (now KHM), learned of the alum treatment from a study visit to the National Museum of Denmark in the Fall of 1904. Ideally a conservation method should preserve surface carvings and maintain the shape of fragments upon drying so that they could be puzzled together into whole objects. This required surfaces which were possible to glue together. In light of the difficulties in securing funds for the recovery and preservation of this find, conservation should also be affordable and efficient. The only method found to fulfill the above criteria was that which used alum salts (Fig. 1) [6]. It was also 

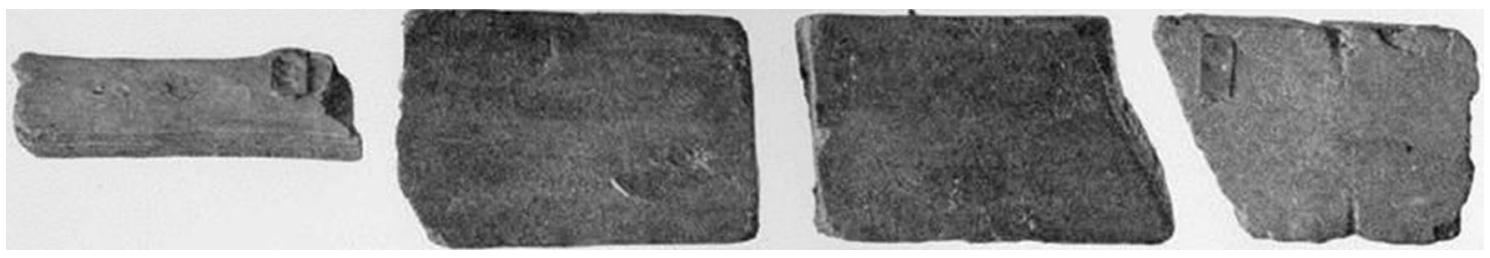

Fig. 1 Testing the alum-treatment on an object where the four pieces fit together, ca. 1905. The right piece was alum-treated. The two pieces in the centre were waterlogged. The left piece was the result of air-drying [6]

likely seen as a reliable treatment as it had been in use for almost 50 years. ${ }^{2}$

The conservation and restoration of the Oseberg finds took place between 1905 and ca. 1912 and involved approximately 400 objects (and thousands of fragments). Approximately $45 \%$ of the finds were made of wood, and of these about $25 \%$ were treated with alum salts (ca. $12 \%$ of the collection). Unique objects such as the ceremonial sleds and saddle were treated with alum salts.

The principle behind the method took advantage of alum salt's high solubility in hot water $\left(\mathrm{ca} .90{ }^{\circ} \mathrm{C}\right)$, and its low solubility in cold water. The waterlogged wood was impregnated with dissolved salts in the hot concentrated solutions, which upon removal from the bath would cool, causing the salts to recrystallize immediately, retaining the shape of the wooden object or fragment. At this point, surfaces had to be thoroughly washed with hot water to prevent the formation of salt deposits.

Most satisfactory results were obtained on wood that was evenly degraded from surface to core, that is, woods one could 'almost stick one's fingers through.' The surviving laboratory journal gives insight into the treatment process for some objects [13]. Treatment times ranged from 2 to $36 \mathrm{~h}$. For objects greater than one centimeter in thickness and for those in very poor condition, the average impregnation time was $24 \mathrm{~h}$. The exact concentration of alum salt was not noted in the laboratory journal, but in the excavation publication, concentrations of two to four parts alum to one part water by weight are mentioned [6]. Higher concentrations were used on more deteriorated finds. In all, three barrels (tønder) of alum were used, ${ }^{4}$ which roughly corresponded to $139 \mathrm{~L}$. Decorative metal nails were removed from most objects before treatment and later replaced.

\footnotetext{
${ }^{2}$ Indeed, the alum treatment applied to archaeological woods in our own experiments [12] clearly gave good results, making it understandable that the treatment was considered to be successful even as late as the early 1970s [8].

${ }^{3}[6]$, p. 102.

${ }^{4}$ [6], p. 102.
}

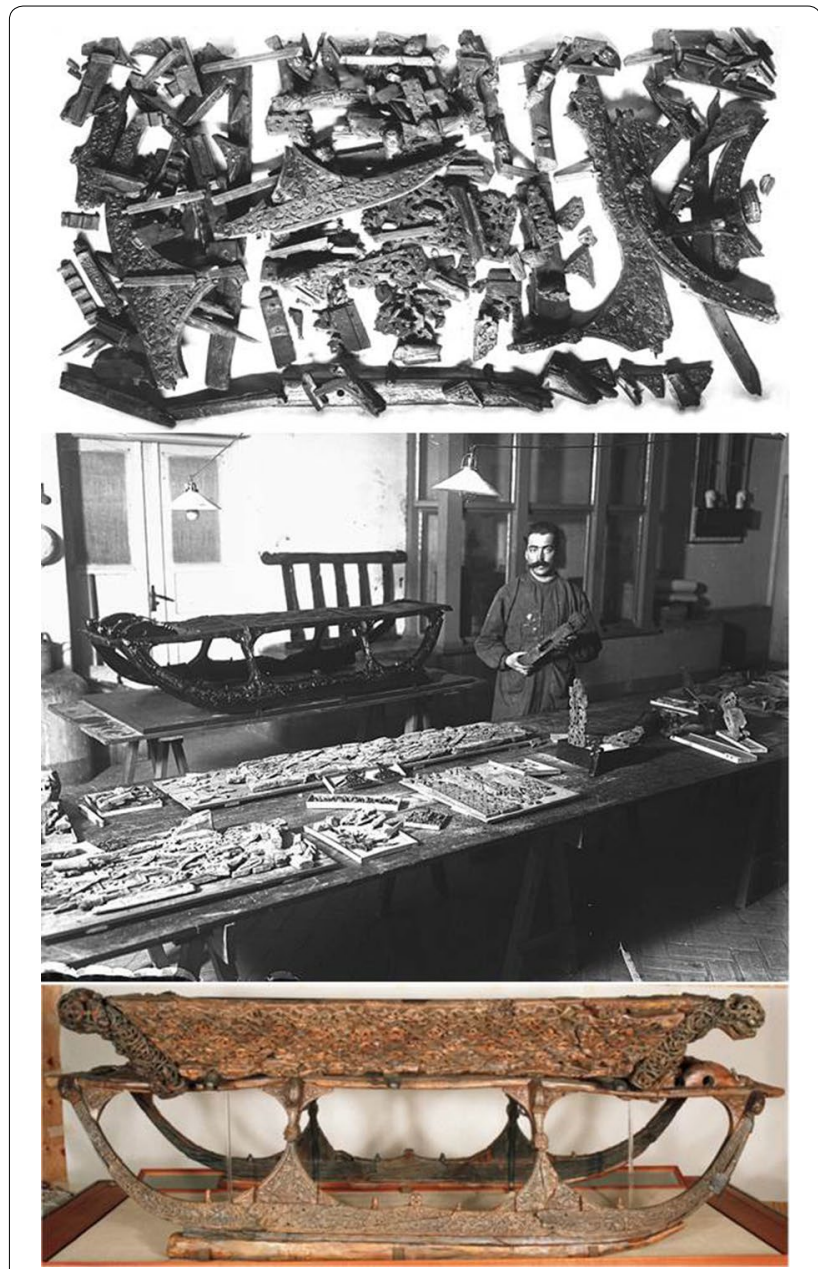

Fig. 2 Each sled is reconstructed from thousands of fragments. Here the Fourth sled is shown during restoration by conservator Paul Johannessen sometime before 1912. Photo: KHM

After impregnation with alum, the fragments were air-dried to constant weight. At this point many of the fragments were impregnated with boiled linseed oil to improve their resilience, since the alum method resulted in wood that was as "brittle as glass. ${ }^{5}$ For smaller objects, linseed oil was applied by brush or by soaking the

\footnotetext{
${ }^{5}[6]$ p. 103.
} 

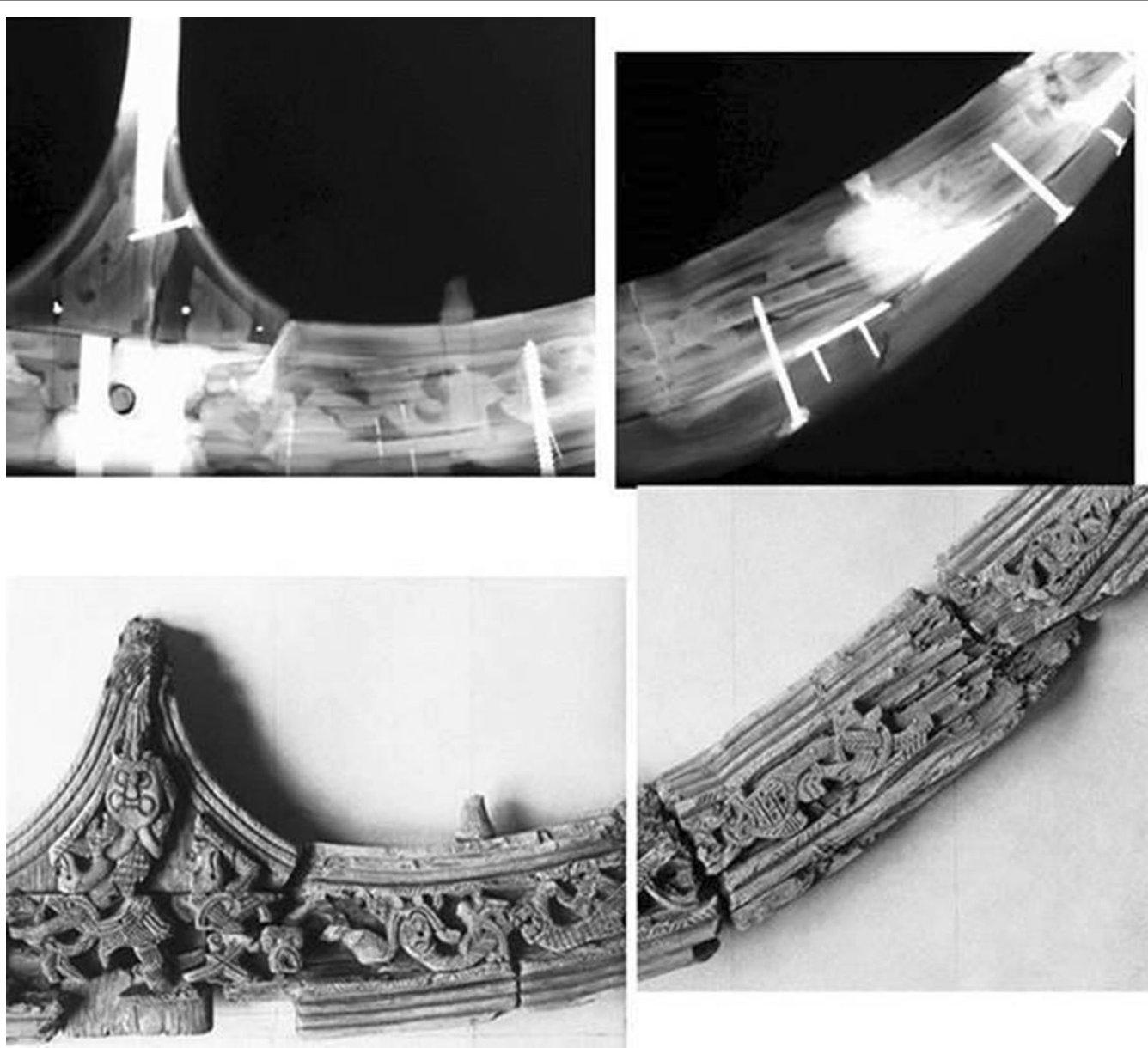

Fig. 3 Detail of the Fourth sled. The X-ray (top) shows the extensive use of metals in its reconstruction. X-ray image: Nancy Child (NL), Susan Braovac (SB), Ragnar Løchen (RL); Photo: KHM; Collage: Nadine Huth (NH)

fragment in it until it was saturated. For larger objects, holes were drilled to improve the penetration. The linseed oil was first thinned with turpentine; successive coats were applied with increasing linseed oil concentrations.

The reconstruction of the fragments into objects involved extensive use of modern materials (Fig. 2). After drying, treated fragments were glued with carpenter's glue (animal-based) or screwed into wooden planks. A gypsum-based putty ${ }^{6}$ filled areas of loss [6], confirmed by recent infrared analyses. ${ }^{7}$ A shellac mixture, possibly

\footnotetext{
${ }^{6}$ The recipe used for this putty is given in Johannessen's journal [13]. 'Dextrine putty: five parts plaster, one part dextrine, pigment'. Dextrine is a starch derivative, made by heating starch (from potatoes, corn) with acid. Also known as British gum [14].

${ }^{7}$ Kutzke, unpublished analyses. The occurrence of calcium sulfate hemihydrate in some samples leads to the assumption that the mentioned plaster is Plaster of Paris, a calcined form of gypsum which was widely used as restoration material. The hemihydrate can attract water over time and transform to gypsum, a process which may be hindered in some cases by the protection of coatings.
}

similar to that described by Bojesen-Koefoed and Stief [15], was used as an adhesive on at least one of the sleds.

$\mathrm{X}$-radiographs taken in the early 2000s revealed extensive usage of screws, pins and metal parts (Fig. 3). In some cases, the metal was fitted flush with the surface of the object by cutting away the wood. Reconstructed objects were coated with a matte varnish (mattlakk) to reduce the shine produced by the linseed oil and to protect the wood from the 'influence of (moisture in the) air' 8 [6]. ${ }^{9}$ An epoxy-based coating was applied during the 1950s as reported by Rosenkvist [16]. Its composition was confirmed by infrared analyses. ${ }^{10}$

\footnotetext{
${ }^{8}$ [6] p. 106.

9 'Matte varnish', applied to the objects after reconstruction has not been further specified in the accounts given of the conservation process.

10 Kutzke, unpublished analyses.
} 


\section{Highly deteriorated wood not treated with alum}

Seven objects bore very finely carved surfaces. One was treated with alum, but it resulted in significantly blurred surface details. Therefore the remaining six objects were kept immersed in water until 1955 or 1956, when a suitable conservation method was found using tertiary butanol and freeze drying [17]. During the 1940s one of the tanks sprung a leak, destroying the animal head post it contained. However, it was saved and has been kept in storage ever since. This object provided a reference sample for chemical analyses, as its degree of degradation during burial was the closest match to those woods which had undergone the alum-treatment. The consistency of the wood from this object was typical for that of degraded archaeological wood, that is, it was weak but not powdery.

\section{Consequences of alum treatment-results of current research}

The following section summarizes this material's most important aspects based on research so far, which includes chemical characterization of the wood, identification of inorganic compounds present, investigations on alum-treated wood's cellular morphology and its interaction with moisture. These topics contributed to a better understanding of the current chemical and physical state of preservation of the wood and thus greater insight into the types of degradation reactions that have occurred/are occurring therein.

\section{Analytical methods used}

Various analytical techniques were used to characterize alum-treated samples. Full descriptions of methods are given in the accompanying references in the text. For clarity, results which are not published are indicated in footnotes. Wood structure was investigated using conventional light microscopy, X-radiography, X-ray tomographic microscopy and scanning electron microscopy (SEM). Non-invasive methods such as colour and $\mathrm{pH}$ measurements were also carried out, using a spectrophotometer and $\mathrm{pH}$ strips, respectively. The chemical composition of the wood fraction was investigated using an array of complementary methods: pyrolysis gas chromatography mass spectrometry (Py(HMDS)-GC/MS), in the presence of derivatizing agent hexamethyl disilazane (HMDS), attenuated total reflection Fourier transform infrared spectroscopy (ATR-FTIR), infrared spectroscopy using synchrotron radiation (SR-IR), different nuclear magnetic resonance (NMR) methods, and gel permeation chromatography (GPC).

To identify and quantify inorganic elements, SEM coupled with energy dispersive spectroscopy (SEM-EDS)

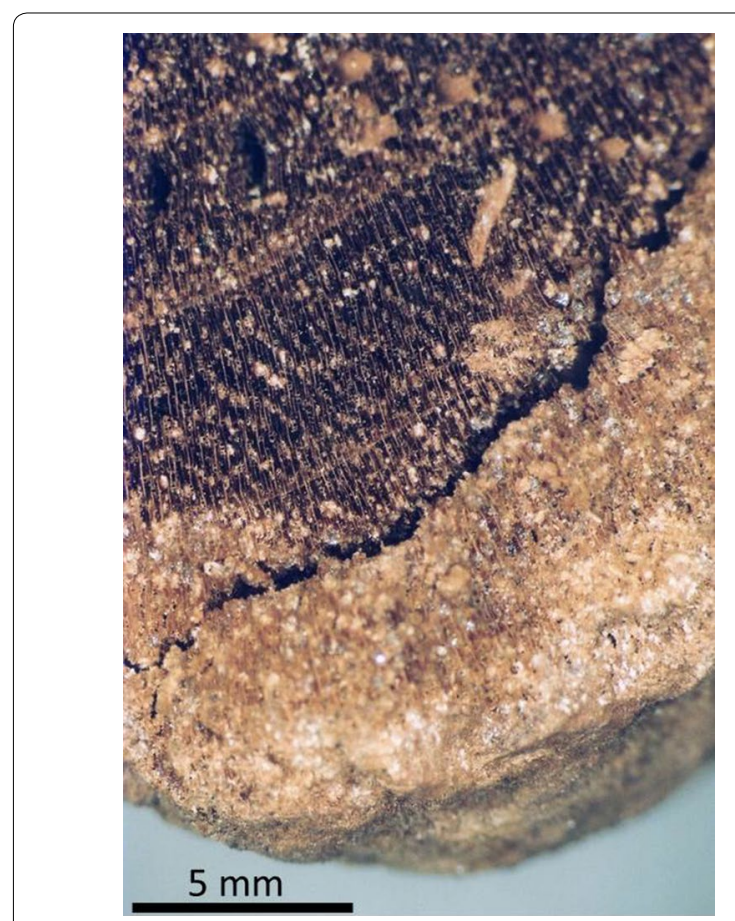

Fig. 4 Stereomicrosope image of alum crystals in wood. The crack has formed along the alum-rich and alum-poor boundary. Photo: SB

and inductively coupled plasma-optical emission spectroscopy (ICP-OES) were used, respectively. Quantification of water-soluble ions was undertaken with ion chromatography (IC). Powder X-ray diffraction and infrared and Raman spectroscopy were used to identify inorganic compounds.

\section{Alum salt}

Alum salts are hard, glossy, transparent or white crystals often large enough to see by eye or at low magnifications (Fig. 4). In written sources about the treatment, only potassium alum is mentioned, $\mathrm{KAl}\left(\mathrm{SO}_{4}\right)_{2} \cdot 12 \mathrm{H}_{2} \mathrm{O}$. However our group has found that in some cases objects also contain substantial amounts of ammonium alum, $\mathrm{NH}_{4} \mathrm{Al}\left(\mathrm{SO}_{4}\right)_{2} \cdot 12 \mathrm{H}_{2} \mathrm{O}$ [18]. Ammonium alum was often sold mixed with potassium alum [19]. Both salts have similar physical properties (melting point, solubility, density) [20].

Alum salt distribution was studied at both macroscopic levels and at higher resolutions [21]. Visual examination and conventional X-radiographs of recently broken fragments from storage showed that alum (and linseed oil, where it was used) penetrated only to a depth of about $5 \mathrm{~mm}$ across the grain and $5 \mathrm{~cm}$ along the grain of the wood (Fig. 4, see also Fig. 6). X-ray tomographic microscopy images show alum crystals in both fibres and vessel elements. It is an uneven, patchy distribution, even 


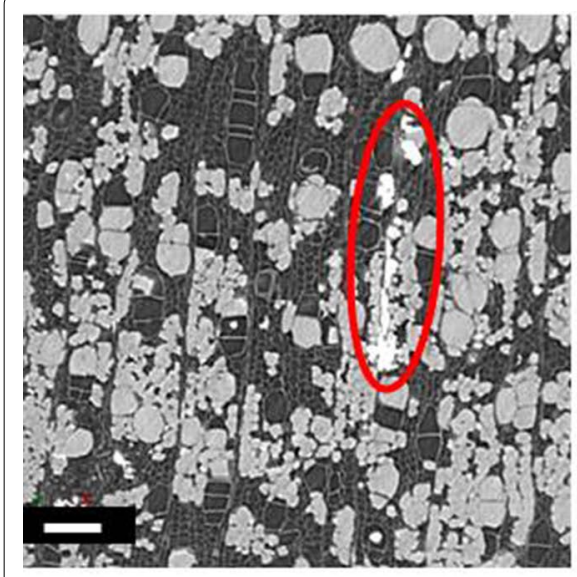

a Transverse

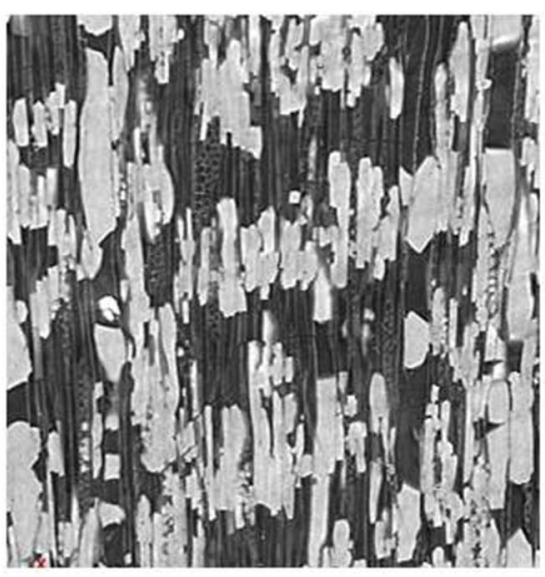

b Tangential

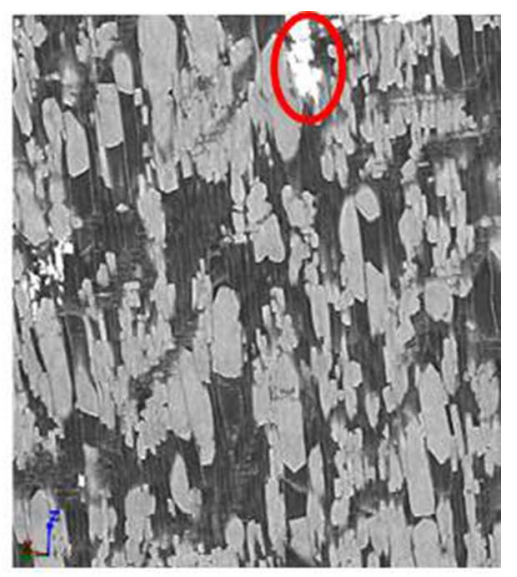

C Radial

Fig. 5 X-ray tomographic images of an Oseberg sample showing distribution of alum salts in the three main directions: transverse (a), tangential (b) and radial (c). Brighter regions (circled) indicate another inorganic compound likely derived from the alum treatment. Images show alum's patchy longitudinal distribution $(\mathbf{b}, \mathbf{c})$. The bar shows $50 \mu \mathrm{m}$. Acquired at the TOMCAT beamline, Paul Scherrer Institute (PSI), Switzerland by HK, MC and SB. Rendered by SB
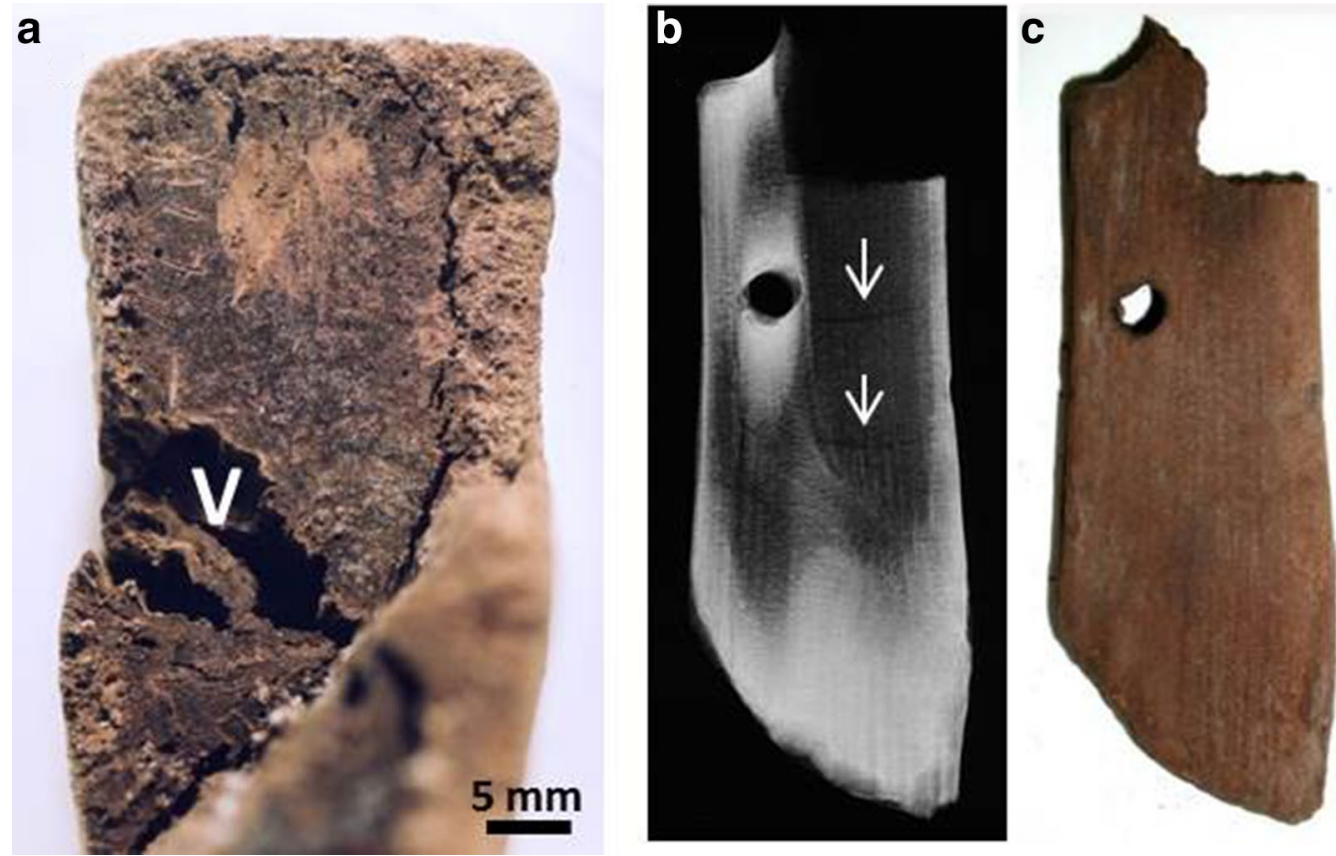

Fig. 6 a Fragment from the Oseberg find, recently broken. The alum-rich layer, ca. $5 \mathrm{~mm}$ thick, surrounds an inner alum-poor core. Inner voids are also evident (' $V$ '). Tension between the alum-rich and alum-poor boundary regions has resulted in crack formation (arrow). b X-ray image of the same fragment revealing minimal alum penetration across the grain, and better penetration along the grain (ca. $5 \mathrm{~cm}$ ). Transverse inner cracks have been formed by drying stresses in the alum-poor core (arrows). These are not visible on the surface, shown in the photograph (c). Xray and photo SB

along the length of a single vessel (Fig. 5). These images also show high density regions in alum-treated woods from Oseberg, due to inorganic deposits which are not alum (Fig. 5a, c). It is uncertain whether these inorganic compounds derive from post-conservation chemical changes in the alum salt or were deposited as different types of salts during the conservation treatment. 


\section{Source of acidity}

$\mathrm{pH}$ measurements show a range of values in alum-treated woods, between $\mathrm{pH} 1$ to $\mathrm{pH} 4.5$, with values generally below $\mathrm{pH} 2.5$, while untreated archaeological woods from Oseberg have a $\mathrm{pH}$ of about 4.5 [22]. It turns out that the source of acidity is the alum treatment itself [12]. Reaction scheme [1] shows solution behavior at room temperature. Heating potassium alum baths to $90{ }^{\circ} \mathrm{C}$ (reaction scheme [2]) causes a significant reduction in solution $\mathrm{pH}$ within a few hours (from pH 3.5 to 2 ), due to the precipitation of small amounts of alunite $\left(\mathrm{KAl}_{3}\left(\mathrm{SO}_{4}\right)_{2}(\mathrm{OH})_{6}\right)$ which only forms in the heated solutions. An excess of sulfur relative to aluminum content has been found in wood samples analyzed by ICP-OES. Ion chromatography showed that most of the sulfur is present as sulfates [21], supporting the hypothesis that acidic sulfate species were absorbed during treatment.

$$
\begin{gathered}
2 \mathrm{KAl}\left(\mathrm{SO}_{4}\right)_{2}+2 \mathrm{H}_{2} \mathrm{O} \rightleftharpoons 2 \mathrm{~K}^{+}+\mathrm{Al}(\mathrm{OH})^{2+}+\mathrm{Al}\left(\mathrm{SO}_{4}\right)^{1+} \\
+\mathrm{H}_{3} \mathrm{O}^{+}+3 \mathrm{SO}_{4}^{2-} \quad \mathrm{pH}=3.5, \mathrm{RT} \\
3 \mathrm{KAl}\left(\mathrm{SO}_{4}\right)_{2}+12 \mathrm{H}_{2} \mathrm{O} \rightarrow \mathrm{KAl}_{3}\left(\mathrm{SO}_{4}\right)_{2}\left(\mathrm{OH}_{6}\right)_{\downarrow}+2 \mathrm{~K}_{(\mathrm{aq})}^{+} \\
+4 \mathrm{SO}_{4}^{2-}{ }_{(\mathrm{aq})}^{2-}+6 \mathrm{H}_{2} \mathrm{O}^{+} \quad \mathrm{pH}=2,90{ }^{\circ} \mathrm{C}
\end{gathered}
$$

Contrarily, heated solutions of ammonium alum maintain a constant $\mathrm{pH}$ of 3 without precipitate formation. ${ }^{11}$ We have found both types of alum in different objects analyzed, one of which is reported in Łucejko et al. [18].

\section{Mechanical damage}

Mechanical damage can be traced back to the alum-treatment. Strength tests carried out in 2002 on alum-conserved wood without linseed oil, revealed that samples retain approximately $2-5 \%$ of the bending strength and $6-8 \%$ of the modulus of elasticity of fresh wood [23]. This is comparable to crisp-bread, whose strength was also measured in the same study. Due to its salt content, the density of alum-treated wood is generally similar or even greater than the density of fresh wood.

The incomplete penetration of alum salts resulted in a wooden object with a thin alum-rich outer layer surrounding an un-conserved wooden core, in agreement with Christensen's descriptions of alum-treated objects at the National Museum of Denmark [1]. Drying stresses thus caused the inner core to shrink while the outer part remained intact, resulting in cracks that are both transverse (across the grain of the wood) and longitudinal, especially in boundary regions where the alum-rich outer layer meets the un-conserved core (Fig. 6, see also

${ }^{11}$ Braovac, unpublished experimental results.

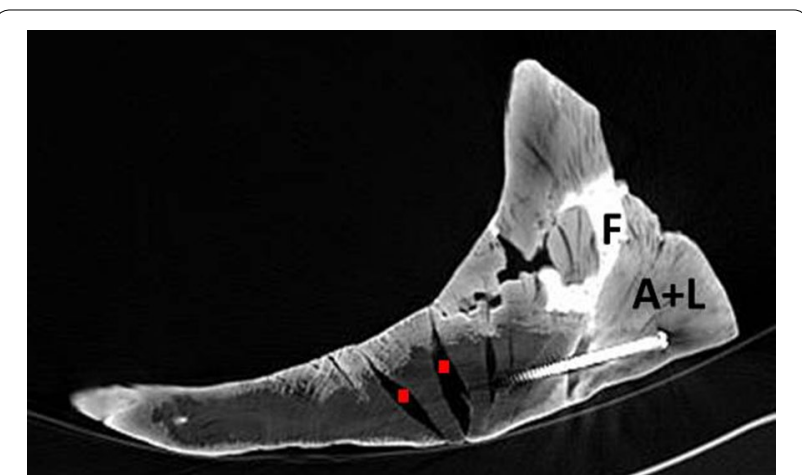

Fig. 7 Collapsed areas of wood, formed during treatment, are visible in this computer tomographic image taken of the Saddle. The red squares show two collapsed areas. Alum salts and the linseed oil have penetrated minimally $(A+L)$, while the varnish is the bright layer on the surface. Fill material $(F)$ and screws originate from restoration after conservation. Acquired by Jan Bill and Sentrum Røntgeninstitutt AS

Fig. 4). New cracks observed on the surface in many of the alum-conserved objects are likely extensions of the inner cracks which have been allowed to propagate due to inadequate physical support.

It is also common to observe longitudinal collapse of wood cells below the surface, due to incomplete penetration and/or osmotic shock arising from the highly concentrated alum solutions used during treatment. Areas of longitudinal collapse appear as voids in cross-sectional breaks of larger fragments, as shown in Fig. 7. Voids can be very small or over $1 \mathrm{~cm}$ in diameter and several $\mathrm{cm}$ in length. Characteristic surface undulations in a fragment are indications that it may have hollow areas. This is seen very clearly in the wheels of the wagon (Fig. 8). Obviously such areas on an object are extremely vulnerable to damage.

New breaks are also related to the post-conservation restoration work. In some objects, cracks are present in areas adjacent to metal brackets, and screws have lost their grip in some cases. X-rays show some metal pins holding fragments are corroding (Fig. 9). The putty has shrunken, sometimes tearing the wood with it.

\section{Wood colour and wood morphology}

Inside new breaks in displayed objects and in wooden fragments retrieved from storage, we often find that the wood had a powdery consistency with little structural integrity. Wood colour ranges from pale beige to dark brown (Fig. 10). The darkest woods are consistently more friable and lose material, even with careful handling [22]. In the stereomicroscope it is possible to see that alumtreated woods are mainly of diffuse-porous types. Wood identity as given in the publication of the find is not 

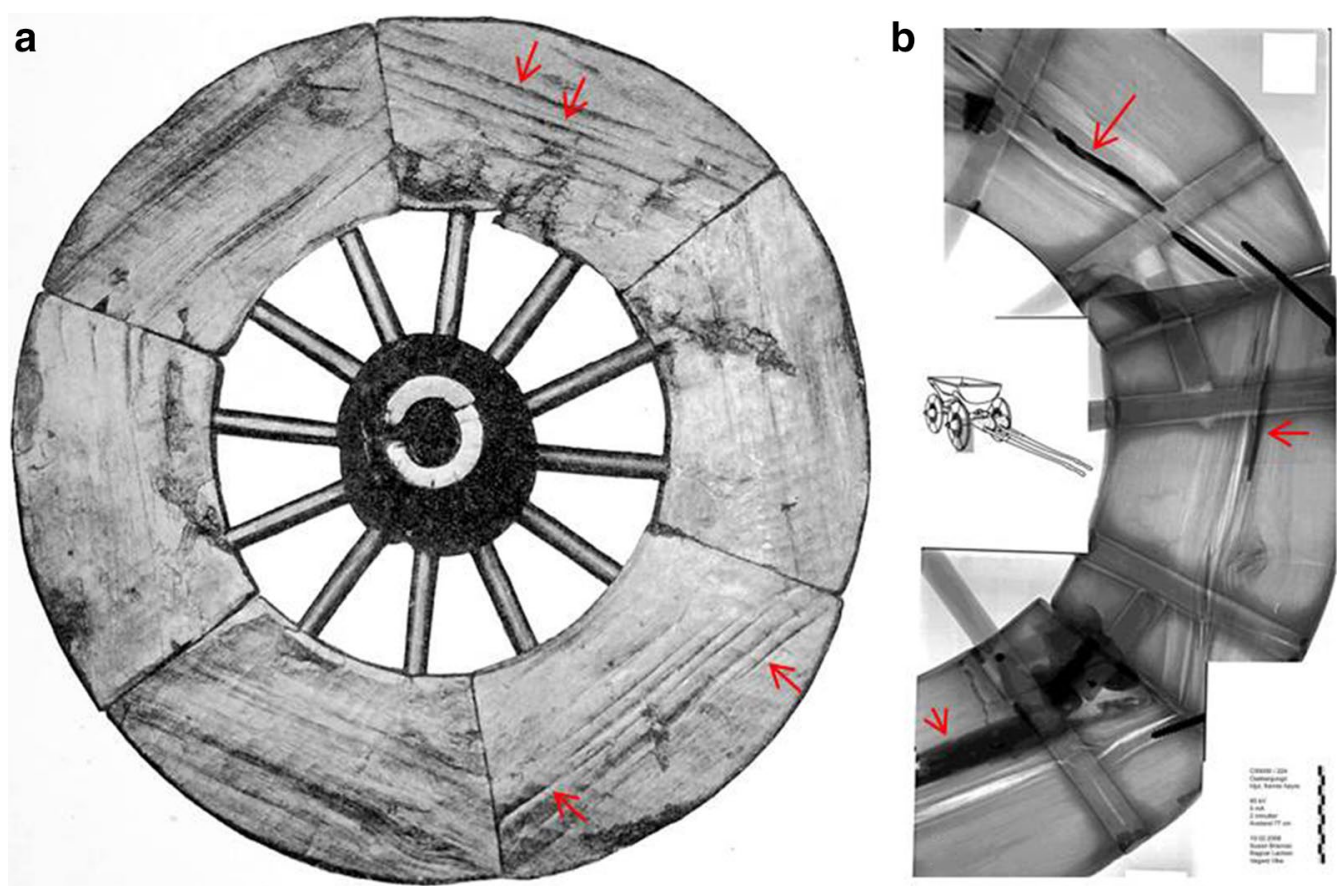

Fig. 8 a Undulations on the surface of alum-treated objects are signs that large voids are present below the surface (arrows). b A recent X-ray image showing a part of another wheel where dark areas (arrows) are voids formed during treatment (Taken from Vike [24])

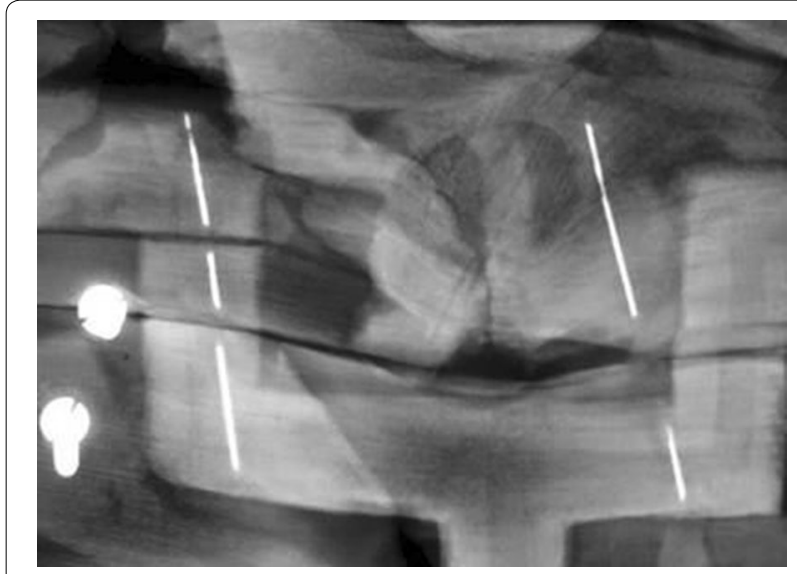

Fig. 9 X-ray image detail of Gustafson's sled, showing corroded metal pins used to hold fragments together in the reconstruction. Acquired by SB, NC, Torunn Klokkernes (TK)

always reliable [6]. ${ }^{12}$ Today, it is not possible to definitely verify wood type for many objects since their present

\footnotetext{
${ }^{12}$ Although the method of wood identification was not reported in the excavation publications, the light microscope almost certainly was not used, as beech (Fagus sp.) - assigned to the majority of objects treated with alum-has so far not been found, but is easily distinguished from birch under high magnification, even in contemporary literature [25].
}

condition is so deteriorated that it is difficult to obtain coherent samples for study under the light microscope. Light microscopy is used to identify woods where more invasive sampling is possible. So far, microscopic examination has identified diffuse-porous hardwoods such as birch (Betula sp.), maple (Acer sp.) and alder (Alnus sp.), and less commonly, ring-porous hardwoods such as oak (Quercus sp.).

SEM images show that the secondary cell walls are highly degraded: they are either missing or completely detached and shrunken. The middle lamella is the main part of the cell wall system that survived and the resilient lignin-rich cell corners also underwent deterioration in some samples. Areas of localized collapse/shrinkage were evident in some cells which did not contain alum. It was not possible to discern the differences observed in macroscopic condition in SEM images. That is, wooden fragments which have clear differences in their structural integrities have similar cell structures. X-ray tomographic microscopy showed that more degraded wood had lower attenuation of the X-ray beam, indicating significant mass loss (Fig. 11). In the worst cases the wood was largely held together by alum salts (Fig. 12). 


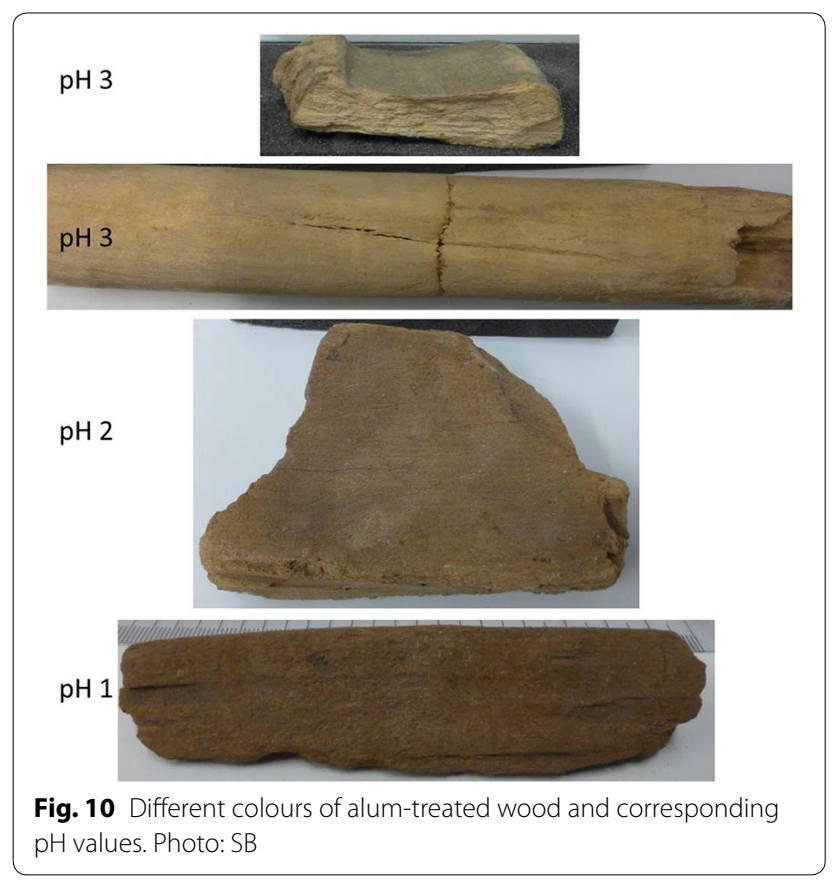

\section{Chemical composition of wood and inorganic compounds identified}

The most pertinent analytical results are summarized below.

\section{Chemical composition of wood}

To investigate the extent of degradation caused by the alum treatment, alum-treated Oseberg wood (without linseed oil) was compared to a sample taken from the untreated, destroyed animal head post mentioned earlier and from an oak sample from the well-preserved
Oseberg ship. Sound woods and waterlogged archaeological woods were also analyzed [21, 26, 27]. Here, the results from analytical pyrolysis (Py(HMDS)-GC/MS) will be highlighted; it is a semi-quantitative method which allows comparison of relative amounts (abundances) of pyrolysis products from different samples.

The most significant feature distinguishing Oseberg alum-treated woods from those which were not treated with alum, observed after analysis by Py(HMDS)-GC/ MS, was the low content of holocellulose (the term for combined cellulose and hemicellulose), ca. 3-20\% relative abundance. What is mainly left is lignin, up to $97 \%$ relative abundance. Analyses of wood from Oseberg not treated with alum and of recently excavated waterlogged archaeological wood showed holocellulose contents ranging from 15 to $68 \%$ and lignin from 32 to $85 \%$ relative abundances, depending on their degree of degradation. These values resemble those for freshly excavated waterlogged archaeological woods from other sites analyzed by analytical pyrolysis, where relative abundances ranged from 14 to $61 \%$ for holocellulose and 34 to $80 \%$ for lignin $[28,29]$. The chemical composition of the wood fraction from alum-treated woods is thus very different from untreated archaeological woods. Sound woods had relative abundances ranging between 58 and $78 \%$ for holocellulose and from 21 to $42 \%$ for lignin [26].

These differences become even more apparent when pyrolysis products are classified into sub-groups. For instance, lignin oxidation pyrolysis products in Oseberg woods are present in up to $80 \%$ relative abundance of total lignin. Oxidation products were mainly composed of carbonyl compounds, such as vanillin and syringaldehyde and carboxylic acids, comprised of syringic and
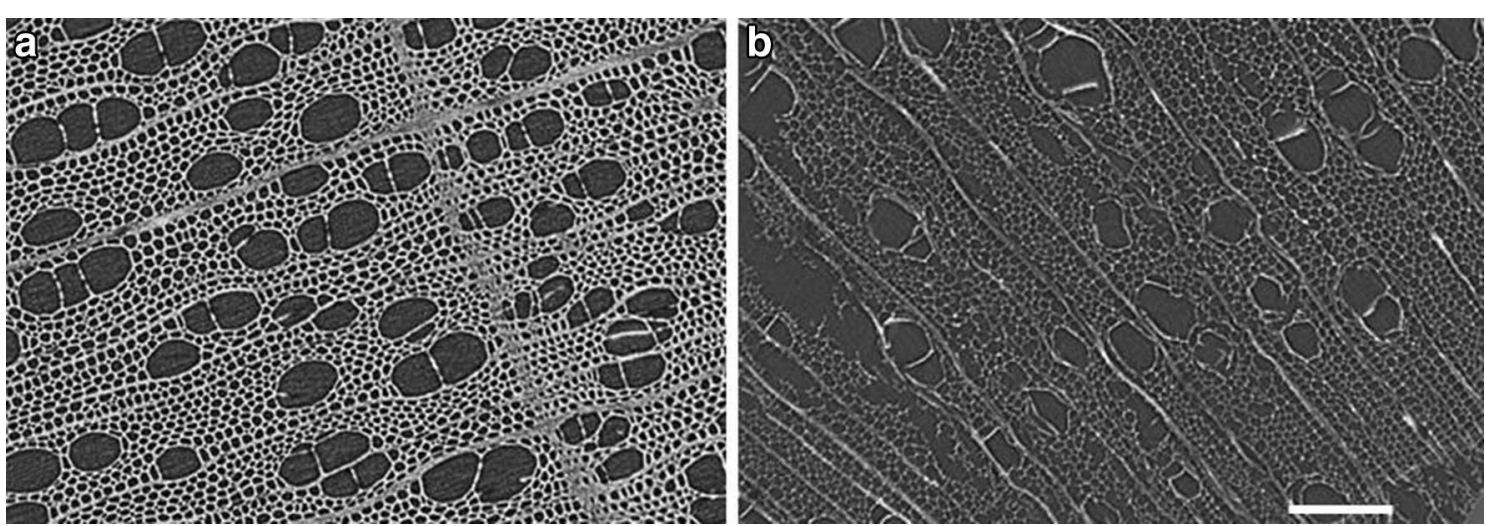

Fig. 11 Both images were taken at the same X-ray exposure. a Fresh birch; $\mathbf{b}$ an Oseberg sample where alum had been removed and the wood freeze dried. The greater attenuation in the fresh birch (the image is brighter) indicates a greater wood density, and hence better state of preservation. The bar shows $50 \mu \mathrm{m}$. Acquired at TOMCAT, PSI by Hartmut Kutzke (HK), Mikkel Christensen (MC) and SB 


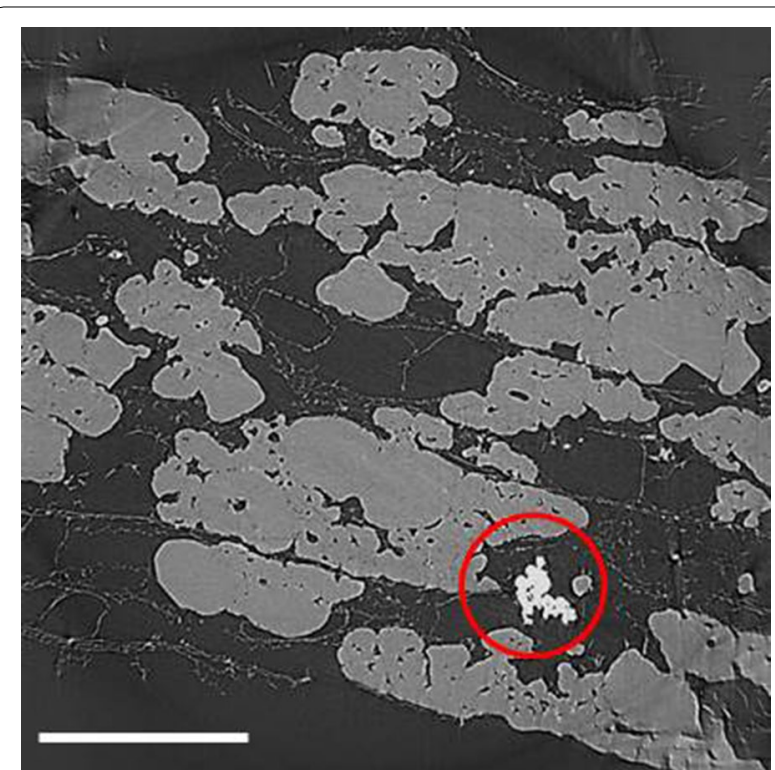

Fig. 12 X-ray tomographic image of Oseberg 185-5. The wood cells are shown by thin grey lines. Alum salts (white/grey) dominate the image. The presence of a denser compound is circled. The bar shows $50 \mu \mathrm{m}$. Acquired at TOMCAT, PSI, by HK, MC and SB

vanillic acids as well as small amounts of para-hydroxy benzoic acid in some samples. In sound wood, lignin oxidation products make up 5-7\% of total lignin [27]. Twodimensional NMR and GPC [30] confirmed the high extent of lignin depolymerization inferred by analytical pyrolysis and ATR-FTIR studies [21, 27].

Likewise, pyrolysis products derived from holocellulose can be divided into sub-categories. In alum-treated woods, polysaccharides formed during pyrolysis are mainly anhydrosugars, which may be considered an index of holocellulose degradation. In sound woods, the most abundant holocellulose category is made up of cyclopentenones such as 3-hydroxy-2-hydroxymethyl-2-cyclopentenone, and E-2,3-dihydroxy-cyclopent-2-enone [31, 32]. The second most abundant group is composed of anhydrosugars which are mainly represented by levoglucosan (1,6-anhydro-beta-D-glucopyranose).

Anhydrosugars are present in different trimethylsilyl (TMS) derivative forms: tri-TMS, di-TMS and monoTMS when the pyrolysis is carried out in the presence of HMDS. The more depolymerized the cellulose and hemicellulose networks, the greater the extent of silylation of anhydrosugars. For example, in an alum-treated fragment from Oseberg the relative abundance of anhydrosugars containing three silyl groups lies between 70 and $90 \%$, while in sound alder tri-silylated anhydrosugars are found in the order of $40 \%$ [18].

Chemical variability can be found within single objects, as exemplified in the so-called 185-series, which is comprised of six fitted fragments from a loom, where there is progressively greater lignin oxidation and lower holocellulose content from one side of the object to the other [21, 26]. This parallels visual condition where the better preserved fragments having better structural integrity are lighter in colour than the less preserved fragments, which were extremely powdery and significantly darker.

Chemical variability was also investigated within individual fragments. Generally, the wood in fragments with alum-rich surfaces without linseed oil coatings was slightly more degraded than that in the alum-poor core, reflected in higher levels of oxidized lignin-derived pyrolysis products [21]. This may either be directly related to the alum-treatment or to the fact that surfaces are generally more degraded than cores in archaeological wood [1]. A slight preservative effect of linseed oil on wood has been observed in one alum-treated fragment containing linseed oil. Here holocellulose levels at the surface were slightly higher and lignin oxidation products were lower than those found in the core of the same fragment, where wood was not coated with oil [18].

\section{Iron and inorganic compounds}

In unrestored objects, the presence of iron originates from the burial environment. The iron content in Oseberg alum-treated wood samples analyzed by ICP-OES was $3.5 \mathrm{mmol} / 100 \mathrm{~g}$ or less $[21,26]$, much lower than that found in other published finds where iron content ranged from ca. 10 to several $100 \mathrm{mmol}$ per $100 \mathrm{~g}$ of sample $(\mathrm{mmol} / 100 \mathrm{~g})$ [33-35].

In restored objects where extensive iron hardware was used, the acidic environment in the alum-treated wood has caused the corrosion of iron rods used in restoration. Some of these rods were accessible for sampling due to new breaks, and in these cases iron-containing minerals were located on the rods themselves and in the wood adjacent to them. These include various forms of both iron sulfates and iron potassium sulfates, demonstrating that iron ions have reacted with alum salts, or their derived products: szomolnokite $\left(\mathrm{FeSO}_{4} \cdot \mathrm{H}_{2} \mathrm{O}\right)$, rozenite $\left(\mathrm{FeSO}_{4} \cdot 4 \mathrm{H}_{2} \mathrm{O}\right)$, krausite $\left(\mathrm{KFe}\left(\mathrm{SO}_{4}\right)_{2} \cdot \mathrm{H}_{2} \mathrm{O}\right)$, goldichite $\left(\mathrm{KFe}\left(\mathrm{SO}_{4}\right)_{2} \cdot 4 \mathrm{H}_{2} \mathrm{O}\right)$, and voltaite $\left(\mathrm{K}_{2} \mathrm{Fe}_{5}^{\mathrm{II}} \mathrm{Fe}_{3}^{\mathrm{III}} \mathrm{Al}\left(\mathrm{SO}_{4}\right)_{12} \cdot 18 \mathrm{H}_{2} \mathrm{O}\right)[36]$.

The corrosion layer on a nail from the Oseberg find which had not been exposed to the alum treatment was found to contain iron carbonate $\left(\mathrm{FeCO}_{3}\right)$, gypsum $\left(\mathrm{CaSO}_{4} \cdot 2 \mathrm{H}_{2} \mathrm{O}\right)$ and iron oxyhydroxides (lepidocrocite and goethite $(\mathrm{FeO}(\mathrm{OH}))$ by XRD [36]. The corrosion layers formed during burial are thus very different from those found on the newer iron rods used to reconstruct the object.

Higher levels of zinc, up to $4 \mathrm{mmol} / 100 \mathrm{~g}$, were present in alum-treated wood than that found in either fresh wood or in Oseberg woods not treated with alum [26, 27]. Zinc 
originates from the water tanks used to store the fragments before treatment with alum salts. In one object, localized salt outbreaks in two regions away from restoration metals contained a mixture of gunningite $\left(\mathrm{ZnSO}_{4} \cdot \mathrm{H}_{2} \mathrm{O}\right)$ and a mineral with composition $\mathrm{K}_{2}\left[\mathrm{Zn}\left(\mathrm{H}_{2} \mathrm{O}\right)_{6}\right]\left(\mathrm{SO}_{4}\right)_{2}$, and $\mathrm{ZnS}$ (sphalerite). Sphalerite contains reduced sulfur and as such was an unusual find, as most sulfur present in the wood is in its oxidized form as sulfate from the alum salt. Reduced sulfur likely originates from the burial environment itself which was near the coast [8], presumably formed through the conversion of sulfates from sea water to sulfides by sulfate reducing bacteria [36].

Other compounds identified include mercallite $\left(\mathrm{KHSO}_{4}\right)$ and alunite $\left(\mathrm{KAl}_{3}\left(\mathrm{SO}_{4}\right)_{2}(\mathrm{OH})_{6}\right)$. Mercallite, which is acidic, has been found in samples which do not contain linseed oil and which are highly degraded, and as such may be another symptom of degradation [21]. Alunite has so far only been identified on surface samples, implying that it formed during treatment and not in posttreatment reactions in the alum salt [36].

A greenish material was found on the surface of a brass screw used to assemble fragments. By means of infrared analyses, the substance was found to be copper oleate, formed by a reaction between the linseed oil and copper from the screw. ${ }^{13}$

\section{Effect of RH on alum-treated wood}

Sorption experiments of pure potassium alum showed that in the range of $30-75 \% \mathrm{RH}$ and at $20{ }^{\circ} \mathrm{C}$, very little moisture was adsorbed [27]. However, mercallite, present in small amounts in the wood is hygroscopic and will migrate under humid conditions. ${ }^{14}$ New needle-like crystals (a form of potassium hydrogen sulfate) formed on the surfaces of fragments of alum-treated Oseberg wood without linseed oil which were maintained at $75 \%$ RH for ca. 2 years before being stored at lower RH levels. ${ }^{15}$ Other experiments on alum-treated Oseberg wood without linseed oil have shown that the migration of these hygroscopic salts accompanies extensive damage of poorly preserved wooden fragments when exposed to extreme RH cycling at slightly elevated temperatures $\left(30{ }^{\circ} \mathrm{C}\right)[33]$.

Regarding wood samples, sorption experiments using the same conditions as above demonstrated that untreated freeze dried archaeological wood and freeze dried Oseberg wood which had its alum removed by washing, showed higher moisture uptake, especially above $70 \% \mathrm{RH}$, than almost all other samples in the

\footnotetext{
${ }^{13}$ Kutzke, unpublished analyses.

${ }^{14}$ Mercallite has a deliquesence point at $86 \% \mathrm{RH}$ and $15^{\circ} \mathrm{C}$ [37].

${ }^{15}$ McQueen and Braovac, unpublished experimental work.
}

study which included: sound wood, archaeological wood recently treated with alum, Oseberg woods retreated by PEG 3000 and Oseberg samples with alum and alum/linseed oil [27]. The exception was for samples containing glycerol, ${ }^{16}$ which had the greatest moisture uptake of all samples due to glycerol's high hygroscopicity.

\section{Linking material knowledge to conservation issues}

In the previous section, a summary of alum-treated wood's material properties was presented. How this material knowledge relates to decisions or actions involving the collection's preservation is discussed here.

\section{Mechanical fragility}

Chemical analyses of alum-treated woods show an extreme form of degradation not normally observed in archaeological wood. Such deterioration cannot only be attributed to natural aging, but is rather heavily influenced by the alum treatment itself. Acid formed in the hot alum solutions has been absorbed by the wood at the time of treatment, and has since caused the slow degradation of wood polymers. The acidic environment has also caused the corrosion of metal rods and pins used to restore the objects and may have accelerated other reactions, such as those between the brass screws and linseed oil. The current rate of degradation reactions is, however, unknown.

The reduced mechanical strength of alum-treated woods is therefore the result of a combination of bacterial degradation during burial, chemical degradation caused by the alum treatment and the mechanical damage originating during treatment and from aging of restoration materials.

Alum salts are unevenly distributed, and in objects greater than $1 \mathrm{~cm}$ in thickness and $10 \mathrm{~cm}$ in length one can expect to find alum-rich and alum-poor zones, implying the likely presence of internal cracks and voids. Areas of collapse can extend to the surface. Thus even single fragments may require very careful handling to avoid further damage. Corrosion of the iron rods used to hold fragments together may produce salts which expand in volume significantly, which in turn may lead to cracking of the adjacent wood or failed repairs.

Alum salts also add significant weight to fragments and in the most degraded samples, wood is more or less held together by alum salts. However, the salts generally do not contribute significantly to the global strength of the fragment. Therefore packing design and display mounts must offer full physical support. In larger fragments,

\footnotetext{
${ }^{16}$ Kindly donated by the National Museum of Denmark.
} 
losses of alum-rich surfaces may trigger extensive material loss from the weaker alum-poor regions.

Linseed oil has penetrated to the same extent as the alum salts, thus it too is concentrated on surfaces. Unlike alum, it generally provides good surface consolidation, which contributes to the preservation of carved surfaces. As it also offers a slight chemically-related preservative effect on the wood polymers, it does not seem necessary to remove it as long as it does not interfere with retreatment.

Improving mechanical properties of the object would be one of the aims in retreatment. Another aim would be to chemically stabilize this wood. Regarding eventual retreatment, aqueous-based methods involve several steps, starting with the immersion of a fragment in water to remove alum salts. The wood is simultaneously deacidified, as most acidic products are also removed during this step. After alum removal and deacidification, the fragment is immersed in a solution containing the strengthening polymer. We are testing two established aqueous methods, using polyethylene glycol (PEG) coupled with freeze drying and Kauramin followed by air drying. The type of PEG used (for example PEG 2000) is solid at room temperature. When dissolved in water, PEG molecules diffuse into the wood and form hydrogen bonds with the wood fabric. Freeze drying allows for lower concentrations to be used $(40 \%, \mathrm{w} / \mathrm{v})$ than that required for air drying, while still offering physical support to the wood cells. In the Kauramin treatment, a 25\% (v/v) solution of Kauramin $800^{\circledR}$, a propriety mixture of melamine and formaldehyde in monomeric and oligomeric forms, diffuses into the wood. The melamine and formaldehyde undergo in situ polymerization when solution conditions approach $\mathrm{pH} 6-7$, resulting in an open melamine-formaldehyde resin network that supports the weakened wood cells [38]. Linseed oil does not appreciably hinder alum removal or impregnation of strengthening polymers. Immersion of the worst preserved fragments has not been successful, as they more or less disintegrate in water. Objects which have been restored will not withstand immersion either. For such objects, solvent-based strengthening agents are being investigated in Saving Oseberg [39-43].

\section{Interaction with moisture}

At the start of our work with the Oseberg collection, it was believed that the powdery nature of the wood was the result of the mechanical destruction of cells due to the dimensional changes of alum salts in response to moisture fluctuations. We have found that potassium alum salts do not take up water in the range $30-75 \% \mathrm{RH}$ at $20{ }^{\circ} \mathrm{C}$, in agreement with the Swedish National Heritage Board's results [4]. Our own experiments show that ammonium alum behaves in a similar manner. ${ }^{17}$ On the other hand, hygroscopic salts present in minor amounts in the wood can migrate in the presence of moisture, possibly even at RH levels below their deliquescence point, as was observed in the formation of needle-like crystals under dryer conditions after storage at $75 \% \mathrm{RH}$. We hypothesize that these crystals result from reactions of mercallite, even though it deliquesces at 86\% RH [37].

Wood samples fully impregnated with alum alone, with a combination of alum and linseed oil or retreated with PEG 3000, are not as sensitive to relative humidity as untreated freeze dried archaeological wood. As long as the impregnating agent is less hygroscopic than wood, it will reduce moisture uptake if it appreciably coats the wood structure. This can be explained by considering that the extremely deteriorated wood is highly porous and that the high degree of lignin oxidation increases the material's chemical polarity. Both factors lead to an increase in the number of interactive sites for water in untreated, degraded wood, resulting in higher equilibrium moisture contents than treated woods [44].

It can therefore be expected that wood in the moreor-less untreated alum-poor regions is more reactive to moisture than the alum-rich surfaces, especially above $70 \% \mathrm{RH}$. Wood from alum-poor zones exposed to the ambient environment through fractures in reconstructed objects can be pulverized by repeated swelling and shrinkage under fluctuating RH conditions, as shown by Mortensen et al. [33]. To prevent this, the RH should be kept relatively constant, and maintained in the range of $40-55 \% \mathrm{RH}$. Retreated objects should be stored at RH levels and fluctuation ranges appropriate for the polymer-wood combination used in retreatment, evaluated through sorption measurements.

\section{Chemical reactivity of inorganic compounds in the wood Alum salt}

Alum salt is the major inorganic compound in the wood. Contrary to previous views, which promoted the idea that alum salts are hygroscopic, we have established that they are not moisture sensitive and thus do not pose a risk for mechanical damage due to $\mathrm{RH}$ fluctuations. Whether alum salts partake in ongoing chemical deterioration reactions, directly or indirectly, is under investigation, as discussed below.

The $\mathrm{pH}$ values of alum-treated woods do not distinguish levels of deterioration very well. This either indicates that acid hydrolysis is not the only reaction involved in degradation or that hydrolytic reactions may also involve aluminum ions, which are electron acceptors

\footnotetext{
${ }^{17}$ Braovac, unpublished experimental work.
} 
just like protons, but are not measurable by $\mathrm{pH}$, which only accounts for proton activity. In acidic solutions at elevated temperatures aluminum ions catalyze isomerization reactions in sugars, such as those which convert glucose into fructose; they also promote dehydration reactions of sugars [45].

Analyses indicate that that the aluminum content is mainly affiliated with alum salts. Whether aluminum ions are capable of undergoing the reactions mentioned above when in the solid state is uncertain. We are looking into the possibility that small amounts of potassium may be leached from potassium alum in the presence of more hygroscopic minerals such as mercallite. This in turn may lead to a destabilization of the alum salt itself, making aluminum more reactive in such cases. The influence of ammonium alum on such reactions is also under investigation. Thus some of the other minerals identified may have arisen through reactions either with alum directly, with the alum salt's breakdown products, or both.

\section{Other inorganic compounds}

The iron-containing minerals identified in the wood can be sources of ferrous ions, which in turn can lead to oxidative degradation of wood [46, 47]. It should be noted, however, that such compounds were generally only found in proximity to the iron rods used in restoration, indicating that iron ions have not migrated very far, and that potential iron-induced reactions are local. We attempted to correlate iron content as determined by ICP-OES with amounts of acidic lignin pyrolysis products, but found only weak correlations. This suggests that iron-induced degradation is likely minor.

There is no evidence in the literature indicating that zinc is involved in wood degradation reactions, but the powder containing both gunningite and $\mathrm{K}_{2}\left[\mathrm{Zn}\left(\mathrm{H}_{2} \mathrm{O}\right)_{6}\right]$ $\left(\mathrm{SO}_{4}\right)_{2}$ is acidic, $\mathrm{pH} 2.5$, and can thus indirectly cause local damage.

The thermodynamic stabilities of the chemical systems containing alum and the other major salts identified are still being researched, as we are interested in knowing whether they pose a preservation threat.

\section{Dealing with acidity and inorganic compounds}

Wood's absorption of excess acidic sulfates produced during the alum treatment has been confirmed by chemical analyses. Besides alum, sulfates are associated with iron, potassium and zinc in several mineral forms. For the salt efflorescence on the surface of an object, in which zinc, iron and alum salts have been identified as well as elemental sulfur, $\mathrm{pH}$ of 2.5 was measured. Such salts likely also contribute to the low $\mathrm{pH}$ values observed in some woods ( $\mathrm{pH} 1)$. However, in the wood samples analysed for sulfate content, the level of sulfates significantly exceeded the levels of metal cations, so the identities of the counter-ions for all acidic sulfate species remains uncertain.

Lack of firm correlations of iron with wood degradation have made us question the necessity to remove it during an eventual reconservation. Such a step may introduce unnecessary risks. Deacidification may be the best option to reduce possible ongoing hydrolytic reactions and local reactions potentially involving iron, since high acidity favours both iron corrosion-observed in the iron hardware used to restore the objects-and iron-catalyzed oxidative processes in wood.

Deacidification may be approached in two ways: either by immersion in water, a step in retreatment methods using aqueous-based polymers such as PEG [4] and Kauramin or by adding a deacidifying agent such as alkaline nanoparticles (NP) suspended in isopropanol [42]. We are investigating both avenues in ongoing experiments on original material. Deacidification by NPs does not extract alum, as alum is insoluble in isopropanol. However, NPs may react with it or with its derived products and form new minerals. Such reactions are being examined as they must be understood before we can recommend this type of deacidification treatment.

\section{Insight into variability in visual and chemical states of preservation}

Chemical variation has been found within single objects where there are alum-rich and alum-poor zones, linseed oil and iron parts. This type of variation is more or less consistently observed in alum-treated wood. However there are also examples of variability in condition within single objects, such as in the so-called 185-series, which are not yet fully understood, despite extensive investigation. Likewise, we do not fully understand the reasons behind the diverse range of visual states of preservation among different objects in the collection. For these objects, we can roughly relate the chemical state of preservation to an object's/fragment's colour and consistency [22]. Generally, the darker the wood, the more powdery it is and the greater is the degradation (extent of oxidation) of the lignin polymers (see Fig. 10). As mentioned earlier, iron content and $\mathrm{pH}$ values show only a modest correlation with visual condition.

Variability in the current state of preservation of the objects may be partly related to the original condition upon recovery. Brøgger et al. [6] noted that there was a range of preservation states, as fragments in very poor condition were treated in alum solutions which had higher concentrations than that used on finds which were less degraded. They also noted that the alum-treatment gave best results on wood that was evenly degraded to the core. Today we observe that the few examples of 
ring-porous woods (such as oak) conserved with alum are in a better state of preservation than alum-treated woods of the diffuse-porous type (such as birch or maple), which may indicate better initial condition, or it may be due to the fact that these fragments are small and saturated with linseed oil. Linseed oil appears to protect the wood to some extent from degradation. In other cases, especially in objects where linseed oil has not penetrated the fragment completely or those without linseed oil, as in the object named 185-series, we see that fragments from a single object display differences in state of preservation which are extreme.

Brøgger et al. [6] also stated that larger fragments were treated for longer periods than smaller fragments. Immersion time in the acidic treatment solutions may be a factor which affects current condition, but it does not explain the differences observed in the 185-series, fragments from which were presumably conserved at the same time. Another possible factor contributing to observed variability in state of preservation may be related to when the object was treated. During the 7-year period of alum-treatment, it is unknown whether fresh alum baths were made regularly, or if baths were merely topped up with alum and/or water as needed. If the latter, older solutions may have had greater acidity due to the steady precipitation of alunite; woods conserved later will have absorbed more acid than woods conserved earlier. Finally, we have found both potassium alum and mixtures of ammonium and potassium alums in the analyzed woods. Current experiments showed that hot $\left(90^{\circ} \mathrm{C}\right)$ ammonium alum solutions do not decrease in $\mathrm{pH}$ as do potassium alum solutions. This may imply that not as much acid has been absorbed by fragments treated in alum mixtures, and therefore they may exhibit less degradation today. Inorganic compounds other than alum are generally present in the wood in much smaller quantities than alum salts, but may nonetheless contribute to degradation through reactions that are not yet understood.

Thus, the type(s) of alum used, their breakdown products, the solution concentration, immersion time, whether linseed oil was used and the time at which treatment took place are variables that may affect current condition. These factors may weigh more heavily than differences in initial burial condition. Unfortunately, little information about such details exists in archival material. Ongoing experiments on the behavior of heated alum solutions over time, and the response of alum salts in the solid state to different temperatures and RH, however, will provide greater insight. Further efforts to relate degree of wood degradation to inorganic content are also underway.

\section{Conclusions and further work}

The conservation research in Saving Oseberg is driven by topics that will contribute to the development of sound, balanced decisions for preserving the Oseberg collection. Preservation strategies will likely involve invasive reconservation to reduce acidity and strengthen the object and/or implementation of preventive measures to slow down deterioration. Dealing with wood in different states of preservation and objects reconstructed to different degrees will require different preservation approaches.

Fundamental research on the alum treatment within the scope of wood conservation is scarce and as such, relevant information from other research fields, such as chemistry, wood science, soil science, mineralogy and geology had to be extracted and related to our investigations, a process which is time-consuming and not always easily adaptable. In effect, we are simultaneously undertaking both fundamental and applied research. Despite these challenges, our interdisciplinary teamwork has yielded new knowledge about this complex material, summarized in this paper. Chemical analysis of alum-treated wood is challenging and requires complementary techniques. We have mentioned analytical techniques which have provided information about the chemical state of preservation of the wood and identified which salts besides alum are present. The significance of analytical results is fed back into the overall conservation context. Our emerging understanding, as well as our analytical approach, is transferable to other alum-treated collections without glycerol and as such we hope that it will be a useful resource.

Answers to research questions still must be shaped by further work. Further investigations of the chemical reactivity of the inorganic compounds identified in the wood may provide more insight into variability in condition. Hopefully, such insight will also provide a better understanding of the current rate of decay in the objects. It is also important to investigate the chemical reactivities of inorganic compounds at the target $\mathrm{pH}$ levels aimed for in deacidification ( $\mathrm{pH} 5-6)$ as they may differ from those at the current acidic levels.

Continuing material-related research runs parallel to that exploring the effects and limitations of different invasive reconservation methods for the simpler objects. Tests on small fragments using two established aqueousbased methods are currently underway: PEG coupled with freeze drying and Kauramin followed by air-drying. These methods are not applicable to highly degraded or extensively restored objects as they require immersion. Research on alternative invasive non-aqueous methods is also underway. Results will provide us with better knowledge about the effect of invasive reconservation strategies for objects in different states of preservation and 
identify the types and extent of damage that could result from retreatment. This knowledge will be used to assess whether invasive retreatments should be applied and if so, which methods are best to use in different cases. Estimates of remaining lifetime of the alum-treated objects will provide a context within which risk may be evaluated, and allow for informed decisions to ensure their future preservation.

\section{Authors' contributions \\ All authors have participated in extensive discussions regarding the conserva- tion implications of the research results. SB was responsible for the main writing of the manuscript, interpretation of wood analyses, microscopy and tomography data acquisition; CM acquired and interpreted data about inorganic compounds and restoration materials; $J$ acquired and interpreted data about wood polymer analyses; HK acquired and interpreted data on restoration materials and tomography data acquisition; and; TK acquired X-radiography data. All authors read and approved the final manuscript.}

\section{Authors' information}

Susan Braovac, Ph.D., archaeological conservator at the Museum of Cultural History who has been working on various aspects of the Oseberg collection since the mid-1990s: risk analyses, chemical analyses, reconservation strategies.

Caitlin M.A. McQueen, Ph.D., chemist at the Museum of Cultural History, who has been doing research in the Saving Oseberg project since 2014 on chemical analysis of alum-treated wood with a focus on inorganic components.

Malin Sahlstedt, M.Sc., conservator at The Swedish National Maritime Museums with experience from archaeological wood preservation projects at The Swedish National Heritage Board (2002-2009), The Vasa Museum (2009present) and University of Oslo in Saving Oseberg (2017-2018).

Hartmut Kutzke, Ph.D., chemist and conservation scientist at the Museum of Cultural History, Oslo. Main research interests: analyses of cultural heritage objects, written sources on art technology, and development of bio-inspired conservation materials.

Jeannette J. Lucejko Ph.D., researcher at the University of Pisa. Research activity concerns the study of modifications undergone by polymers in archaeological waterlogged wooden artefacts by means of mass spectrometric methods.

Torunn Klokkernes, Ph.D., senior conservator and former head of department at the Museum of Cultural History. Research interests are the technology and material science of archaeological and historic artefact materials.

\section{Author details \\ 1 Department of Collection Management, Museum of Cultural History, University of Oslo, Postbox 6762, St. Olavs plass, 0130 Oslo, Norway. ${ }^{2}$ Depart- ment of Chemistry and Industrial Chemistry, University of Pisa, 56124 Pisa, PI, Italy. ${ }^{3}$ Present Address: Collections Unit Vasa Museum, P.O.Box 27131, 102 52 Stockholm, Sweden.}

\section{Acknowledgements}

This work was carried out as part of the Saving Oseberg project, funded by the Norwegian Ministry of Education and Research and University of Oslo. X-ray tomographic microscopic imaging was undertaken under the guidance of beamline scientist Dr. Rajmund Mokso at TOMCAT, Paul Scherrer Institute (PSI), Villingen, Switzerland. Rendering of imaging data was accomplished at SINQ, PSI with assistance from Dr. David Mannes. The authors would like to thank Dr. Louis Boumans and the reviewers for their constructive feedback on the manuscript.

\section{Competing interests}

The authors declare that they have no competing interests.

\section{Availability of data and materials}

The datasets used and/or analysed during the current study are available from the corresponding author on reasonable request.

\section{Publisher's Note}

Springer Nature remains neutral with regard to jurisdictional claims in published maps and institutional affiliations.

Received: 15 October 2018 Accepted: 17 December 2018

Published online: 24 December 2018

\section{References}

1. Christensen BB. The conservation of waterlogged wood in the National Museum of Denmark: with a report on the methods chosen for the stabilization of the timbers of the viking ships from Roskilde Fjord, and a report on experiments carried out in order to improve upon these methods. Copenhagen: The National Museum of Denmark; 1970. p. 118

2. Madsen $\mathrm{HB}$, Andersen JH. Preservation of prehistoric objects in Denmark, 1807-32. In: Brajer I, editor. Conservation in the Nineteenth Century. London: Archetype Publications; 2013. p. 219-32.

3. Eaton JW. The preservation of wood by the alum process, vol. XV. Gainesville: Florida Anthropologist; 1962. p. 115-7.

4. Häggström C, Lindahl K, Sahlstedt M, Sandström T. Alum-treated archaeological wood: characterization and re-conservation. Gotland: Riksantikvarieämbetet; 2013. p. 131.

5. Bonde N, Christensen AE. Dendrochronological dating of the viking age ship burials at Oseberg, Gokstad and Tune, Norway. Antiquity. 1993;67:575-83.

6. Brøgger AW, Shetelig H, Falk H. Osebergfundet. Kristiania: Den norske stat; 1917.

7. Bojesen-Koefoed IM. Re-conservation of wood treated with alum in the 1920s_challenges and strategies. In: Strætkvern K, Williams E, editors. Proceedings of the 11 th ICOM group on wet organic archaeological materials conference, Greenville 2010. Greenville: ICOM-CC-WOAM; 2012. p. 497-502.

8. Rosenqvist AM. The Oseberg find, its conservation and present state. Colloque sur l'altération du bois-symposium on the weathering of wood ICOMOS, Ludwigsburg, Allemagne/Germany 8-11 VI 1969: International Council of Monuments and Sites; 1972. p. 77-87.

9. Jakobsen T. The Museum of Nordic Antiquities 1807-91: exhibition and conservation. Acta Archaeol. 2004;75(2):95-128.

10. Herbst CF. Om bevaring af oldsager af træ fundne i törvemoser. Antiquarisk tidsskrift; 1861. p. 174-6.

11. Speerschneider CA. Behandling af oldsager af træ, som ere fundne i moser for at bevare dem i deres oprindelige form og farve. Antiquarisk Tidsskrift; 1861. p. 176-8.

12. Braovac $\mathrm{S}$, Kutzke $H$. The presence of sulfuric acid in alum-conserved wood_origin and consequences. J Cult Herit. 2012;13(3):S203-8.

13. Johannessen P, Rosenqvist AM. Præparering og restaurering af Osebergfundet. Museum of Cultural History Archives; 1905-1915; 1955-1956.

14. Meyer K. Vareleksikon. 5th ed. Glahn H-E, Bjørn EA, Laruents S, editors. København: Aschehoug Dansk Forlag; 1941.

15. Bojesen-Koefoed IM, Stief M. Initial conservation and mounting. In: Crumlin-Pedersen O, Trakadas A, editors. Hjortspring: a pre-roman Ironage warship in context, vol. 5. Roskilde: Viking Ship Museum; 2003. p. 37-43.

16. Rosenqvist AM. The stabilizing of wood found in the Viking ship of Oseberg: part I. Stud Conserv. 1959;4(1):13-22.

17. Rosenqvist AM. The stabilizing of wood found in the Viking ship of Oseberg: part II. Stud Conserv. 1959;4(2):62-72.

18. Łucejko JJ, La Nasa J, McQueen CMA, Braovac S, Colombini MP, Modugno F. Protective effect of linseed oil varnish on archaeological wood treated with alum. Microchem J. 2018;139:50-61.

19. Thorpe TE. A dictionary of applied chemistry. London: Longmans, Green, and Co., reprinted by HardPress Publishing, Miami; 1918.

20. Weast RC, Astle MJ, editors. CRC handbook of chemistry and physics, 48th ed. West Palm Beach: CRC Press, Inc; 1967.

21. McQueen CMA, Tamburini D, Łucejko JJ, Braovac S, Gambineri F, Modugno F, et al. New insights into the degradation processes and influence of the conservation treatment in alum-treated wood from the Oseberg collection. Microchem J. 2017;132:119-29. 
22. Łucejko JJ, Tamburini D, Braovac S, McQueen C, Gambineri F. Saving Oseberg January 2013-September 2016 Technical Report Part 1: Analyses and characterization of alum-treated wood without other additives. Oslo: Museum of Cultural History, University of Oslo; 2017.

23. Hoffmann P, Schwab E, Bonde N. Report on strength tests performed on wood samples from the Gokstad Ship and boats, and from the Oseberg finds complex, and some observations on strakes from the Gokstad, Oseberg and Tune ships. In: Bøe A, editor. Vikingskipsseminaret. Oslo: University of Oslo; 2002. p. 60-74.

24. Vike V. Oppstøtting av vognen fra Osebergfunnet-Revita delprosjekt 5.4.1, internrapport. Internal REVITA report. Oslo: Kulturhistorisk museum, Universitetet i Oslo; 2008.

25. Petersen OG. Diagnostisk vedanatomi af NV Europas træer og buske; 1901.

26. Braovac S, Tamburini D, Łucejko JJ, McQueen C, Kutzke H, Colombini MP. Chemical analyses of extremely degraded wood using analytical pyrolysis and inductively coupled plasma atomic emission spectroscopy. Microchem J. 2016;124:368-79.

27. Braovac S. Alum-treated wood. Material characterization. A case study of the Oseberg finds. Copenhagen: The Royal Danish Academy of Fine Arts, Schools of Architecture, Design and Conservation; 2015.

28. Łucejko JJ, Zborowska M, Modugno F, Colombini MP, Prądzyński W. Analytical pyrolysis vs. classical wet chemical analysis to assess the decay of archaeological waterlogged wood. Anal Chim Acta. 2012;745:70-7.

29. Tamburini D. From the burial environment to the laboratory: the analytical challenge of archaeological wood. Pisa: University of Pisa; 2016.

30. Zoia L, Tamburini D, Orlandi M, Łucejko JJ, Salanti A, Tolppa E-L, et al. Chemical characterisation of the whole plant cell wall of archaeological wood: an integrated approach. Anal Bioanal Chem. 2017:409(17):4233-45.

31. Tamburini D, Łucejko JJ, Pizzo B, Mohammed MY, Sloggett R, Colombini MP. A critical evaluation of the degradation state of dry archaeological wood from Egypt by SEM, ATR-FTIR, wet chemical analysis and Py(HMDS)GC-MS. Polym Degrad Stab. 2017;146:140-54.

32. Łucejko JJ, Mattonai M, Zborowska M, Tamburini D, Cofta G, Cantisani E, et al. Deterioration effects of wet environments and brown rot fungus Coniophora puteana on pine wood in the archaeological site of Biskupin (Poland). Microchem J. 2018;138:132-46.

33. Mortensen MN, Chaumat G, Gambineri F, Kutzke H, Łucejko JJ, McQueen CMA, et al. Climatically induced degradation processes in conserved archaeological wood studied by time-lapse photography. Stud Conserv. 2018. https://doi.org/10.1080/00393630.2018.1490103.

34. Almkvist G, Persson I. Extraction of iron compounds from wood from the Vasa. Holzforschung. 2006;60(6):678-84.

35. Almkvist G, Persson I. Degradation of polyethylene glycol and hemicellulose in the Vasa. Holzforschung. 2008;62(1):64-70.
36. McQueen CMA, Tamburini D, Braovac S. Identification of inorganic compounds in composite alum-treated wooden artefacts from the Oseberg collection. Sci Rep. 2018;8(1):2901.

37. Mullin JW. Crystallizer design and operation. Crystallization. 4th ed. Butterworth-Heinemann: Oxford; 2001. p. 403-77.

38. Hoffmann P, Wittköpper M. The Kauramin method for stabilizing waterlogged wood. In: Bonnot-Diconne C, Hiron X, Tran K, Hoffmann P, editors. Proceedings of the 7th ICOM group on wet organic archaeological materials conference. Grenoble: Arc-Nucléart; 1999. p. 163-6.

39. McHale E, Braovac S, Steindal CC, Gillis RB, Adams GG, Harding SE, et al. Synthesis and characterisation of lignin-like oligomers as a bio-inspired consolidant for waterlogged archaeological wood. Pure Appl Chem. 2016;88(10-11):969-77.

40. Wakefield JMK, Gillis RB, Adams GG, McQueen CMA, Harding SE. Controlled depolymerisation assessed by analytical ultracentrifugation of low molecular weight chitosan for use in archaeological conservation. Eur Biophys J. 2018. https://doi.org/10.1007/s00249-018-1290-6.

41. Christensen M, Kutzke H, Hansen FK. New materials used for the consolidation of archaeological wood - past attempts, present struggles, and future requirements. J cult Herit. 2012;13(3):S183-90.

42. Andriulo F, Braovac S, Kutzke H, Giorgi R, Baglioni P. Nanotechnologies for the restoration of alum-treated archaeological wood. Appl Phys A. 2016;122(4):322.

43. Andriulo F, Giorgi R, Steindal Calin C, Kutzke H, Braovac S, Baglioni P. Hybrid nanocomposites made of diol-modified silanes and nanostructured calcium hydroxide. Applications to Alum-treated wood. Pure Appl Chem. 2017:89(1):29-39.

44. Foston M, Ragauskas AJ. Changes in the structure of the cellulose fiber wall during dilute acid pretreatment in Populus studied by ${ }^{1} \mathrm{H}$ and ${ }^{2} \mathrm{H}$ NMR. Energy Fuels. 2010;24(10):5677-85.

45. Gupta D, Ahmad E, Pant KK, Saha B. Efficient utilization of potash alum as a green catalyst for production of furfural, 5-hydroxymethylfurfural and levulinic acid from mono-sugars. RSC Adv. 2017;7(67):41973-9.

46. Emery JA, Schroeder HA. Iron-catalyzed oxidation of wood carbohydrates. Wood Sci Technol. 1974;8(2):123-37.

47. Henry WP. Non-enzymatic iron, manganese, and copper chemistry of potential importance in wood decay. In: Goodell B, editor. Wood deterioration and preservation, vol. 845., ACS Symposium SeriesWashington DC: American Chemical Society; 2003. p. 175-95.

\section{Submit your manuscript to a SpringerOpen ${ }^{\circ}$ journal and benefit from:}

- Convenient online submission

- Rigorous peer review

- Open access: articles freely available online

- High visibility within the field

- Retaining the copyright to your article

Submit your next manuscript at springeropen.com 